\title{
DC RESISTIVITY STUDIES OF SHALLOW GEOLOGY IN THE VICINITY OF VISTULA RIVER FLOOD BANK IN CZERNICHÓW VILLAGE (NEAR KRAKÓW IN POLAND)
}

\author{
WŁoDZIMIERZ JERZY MoŚCICKI, GRZEGORZ BANIA, MiCHAŁ ĆWIKLIK, ALEKSANDRA BORECKA \\ AGH University of Science and Technology in Kraków, Faculty of Geology, Geophysics and Environmental Protection \\ e-mail: moscicki@geol.agh.edu.pl,bania@agh.edu.pl,mcwiklik@geol.agh.edu.pl, aborecka@agh.edu.pl
}

\begin{abstract}
DC resistivity methods, soundings and Electrical Resistivity Tomography, were applied to study shallow geology in the place of planned construction of an experimental flood bank. The geoelectrical surveys provided quantitative information about the spatial presence of the various geoelectrical/geological layers: alluvial soils, sands, gravels and clays. ERT allowed maps to be constructed showing subsurface structure. A combination of geoelectrical and geological information resulted in a much better identification of the geological structure.
\end{abstract}

Key words: DC resistivity methods, vertical electrical soundings, Electrical Resistivity Tomography, shallow geology, flood bank, Quaternary, geophysics in civil engineering

\section{INTRODUCTION}

In Czernichow village on the Vistula River (Kraków county), a construction of an experimental flood bank project: "Extensive monitoring of dynamic and static condition of flood banks in a continuous mode with an option for structural changes occurrence simulation and damage risk evaluation" (in short ISMOP - Computerized Monitoring System of Flood Banks) is being planned. The project is realized within the Program of Applied Research financed by the National Centre for Research and Development. One of the most important things when planning such an engineering project is the geological structure recognition and identification of soil properties. In order to recognize electrical resistivity distribution in the geological medium and describe relations between resistivity and near surface sediments (to about 10-15 m above the ground level), geoelectrical measurements were carried out. The geoelectrical methods are effective in the alluvial sediments recognition (Kalicki and Mościcki [9], Mościcki [14]) that dominate in the study area. This is due to the fact that the electrical resistivity of soils (in particular non or poorly consolidated) depends on porosity, pore filling, type of porous medium, content of a silty/sandy component, etc. Simultaneously, the aforementioned properties may have a significant impact on mechanical properties of the soils. This is important in terms of stability of the planned engineering object.

\section{METHOD}

In the field measurements two resistivity methods were involved: Vertical Electrical Sounding (VES) and Electrical Resistivity Tomography (ERT).

Vertical Electrical Sounding (Koefoed [10]) is the basic method for conducting resistivity reconnaissance measurements (e.g., Mościcki [13]). The main aim of the method is to determine the subsurface resistivity changes against depth. A four electrode Schlumberger array with 14 spacings: $\mathrm{AB} / 2=1.39,1.93,2.68, \ldots$, $100 \mathrm{~m}$ and $\mathrm{MN} / 2=0.4,2.0$ and $10 \mathrm{~m}$ were used. A quantitative analysis of the VES curves was made with the use of proprietary software - RESIS package (Department of Geophysics, AGH - UST) and IPI2WIN software (Bobachev [3]). The inversion RMS error was similar in all the cases and did not exceed 3\%.

Electrical Resistivity Tomography (Dahlin [6], Loke [11]) is an effective method of resistivity measurements and allows 2D/3D geoelectrical structure recognition. The method allows, as well, monitoring of geological medium (involving i.a. flood banks, e.g., Johansson and Dahlin [8], Bestyński et al. [2], Oh [15], Case [5]). In the case of a non-flat surface, geodetic 
levelling of a survey line is required. This way, inversion process would be more adequate (e.g., Bania [1]). The geoelectrical survey in Czernichów village was made with the use of GDRM-VAR system with a 96electrode switch box. The basic electrode spacing was $a=1 \mathrm{~m}$. Due to the most favourable signal to noise ratio and the best vertical sensitivity the Wenner alpha array was applied. The Wenner array spacings were $n=1,2,3,4,5,6,8,10,13$ and $16 a$. The ERT data was inverted with Res2dinv software (Geotomo Software - www.geoelectrical.com). The robust norm inversion (Loke [11], Loke et al. [12]) was applied because it was more effective than the default option (the robust option gave lower values of RMS error). The RMS error, in all the cases, was lesser than $2 \%$, which proves the good quality of the data.

The result of the measurement in the resistivity methods is an apparent resistivity, $\rho_{a}$. Its value is determined by the resistivity distribution in a medium, geological structure and characterization of measurement array. Apparent resistivity cannot be identified with electrical resistivity of a geological medium, though it has the same unit $-\Omega \mathrm{m}$.
The result of apparent resistivity data inversion is the distribution of a true electrical resistivity, more accurately - the interpreted resistivity. This term is more proper as the resistivity values received in an inversion process can differ from the real electrical resistivity distribution. This difference may be caused by an ambiguity of inverted geophysical data. The ambiguity causes the interpreted models to be equally correct (in a sense of conformity with the field data), yet, have different properties and geometry.

The quantity interpretation results of the VES survey line are shown as 1D (quasi 2D) interpreted resistivity section. The 2D ERT inversion results are presented as a 2D interpreted resistivity section.

\section{STUDY AREA}

The study area (Fig. 1) is located within the Agricultural Secondary School (Zespół Szkół Rolniczych Centrum Kształtowania Ustawicznego) in Czernichów. The village is located ca. $30 \mathrm{~km}$ south-west of

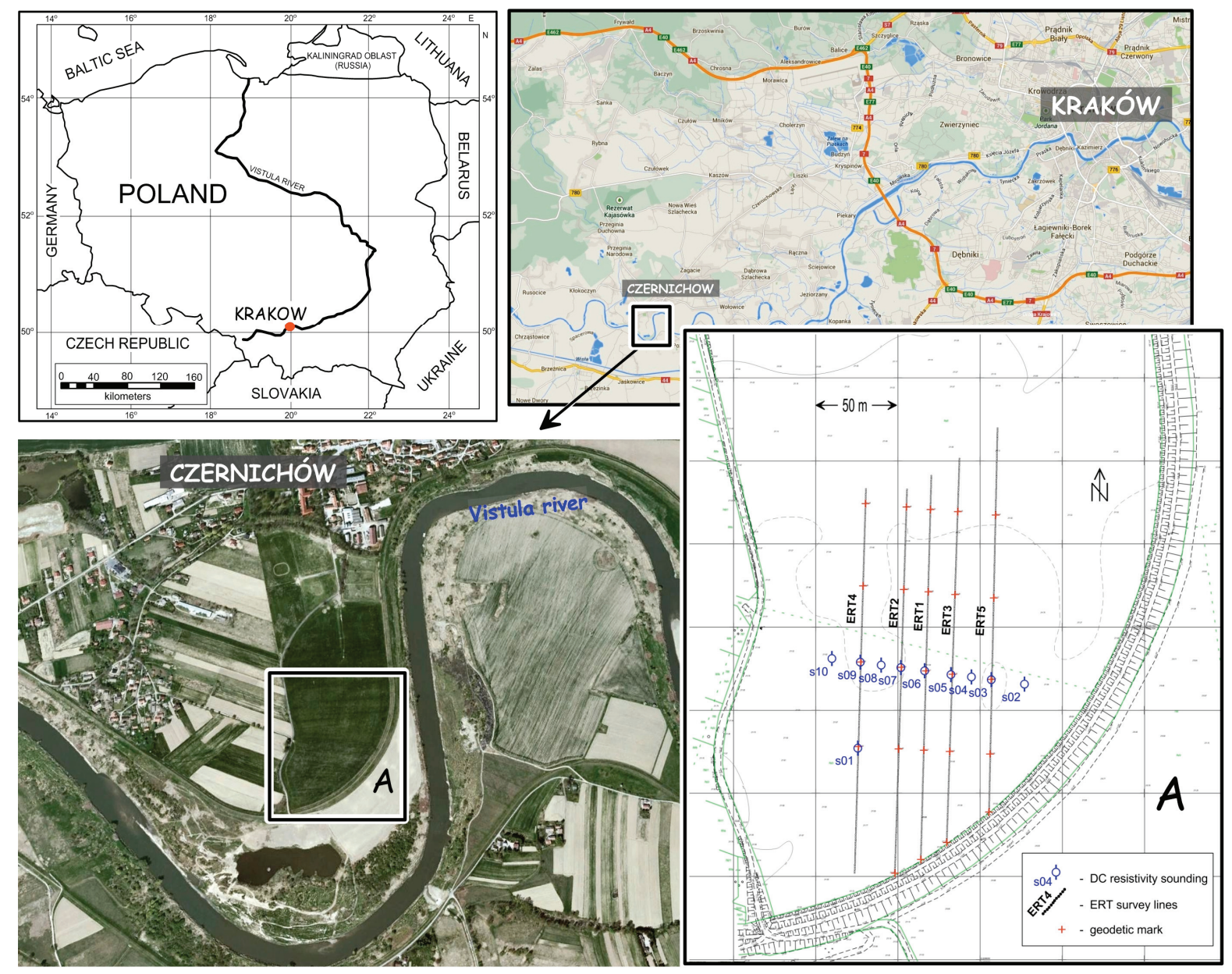

Fig. 1. The study area location 
Kraków city centre. It is a part of the right - bank terrace of the Vistula River. Ordinates of the area in the limits of the experimental flood bank fluctuate between 211.2 and 211.7 MASL. The study area is separated from the river by $4.5 \mathrm{~m}$ high flood bank. An elevation is visible in the north, comprising uplifted elements of an isolated horst hill divided by graben - the sink of the Vistula valley (Borecka et al. [4], Golonka [7]).

\subsection{ELEMENTS OF GEOLOGICAL STRUCTURE}

Archival data and geotechnical studies performed made it possible to propose a preliminary model of shallow geological structure (Borecka et al. [4], Golonka [7]).

The study area is a part of the Carpathian Foreland Basin and the structure of the planned flood bank is formed of Quaternary, Tertiary and Jurassic sediments.

Upper Jurassic (Oxford stage) sediments are composed of light gray, non-bedded, siliceous rocky limestones locally containing black flint. The limestone outcrops are being observed in the north side of the study area.

The Skawina formations are built from marine Miocene sediments, mainly represented by gray, silty clays with silt laminas. These sediments fill the irregularities of limestone ceiling and tectonic depressions.

The study area lies in the Vistula valley which is compounded from Miocene clay sediments and is filled with Holocene clastic sedimentary rocks. A batch of Quaternary (Holocene) sediments lies on Miocene clays. The lowest part of the profile is formed mainly by sandy gravels and gravels, progressing into medium sands. They form alternate layers of different granulometric composition - dusts; silty, sandy dusts; silty sands, medium sands.

\subsection{HYDROGEOLOGICAL CONDITIONS}

The groundwater level was drilled in Quaternary sands and gravels. The level expands constantly and remains in close hydraulic relation to the near Vistula River. As the Vistula's riverbed is in near proximity, the fluctuations of groundwater level correlate with the river level. During the measurements, an average Vistula's water table level was 204.55 MASL. The groundwater level is non-defined and lies at 5-6 MBGL (Borecka et al. [4]).

The groundwater drains the area in the SE direction to the Vistula River. Quaternary aquifer is mainly supplied by infiltrating precipitation water. Isolation of the aquifer is poor or does not exist at all (Borecka et al. [4]).

\subsection{THE SCOPE OF GEOELECTRICAL RESEARCH}

The soundings were conducted at 11 stations (Fig. 1) and the array NS azimuth was applied. On the S06 station, a so-called Azimuthal Vertical Electrical Sounding was carried out (with NS and EW azimuth). The soundings S02-S10 were grouped on one survey line, perpendicular to the longitudinal axis of the planned object.

Along the five survey lines the ERT measurements were carried out (Fig. 1). The ERT-1, ERT-2 and ERT-3 survey lines were located in the area of the planned experimental flood bank. The length of the survey lines was $231 \mathrm{~m}$. The ERT measurements on the ERT-1, 2 and 3 survey lines were carried out in July and on the ERT-4 and 5 survey lines at the turn of September and October 2013.

\section{GEOELECTRICAL RESEARCH RESULTS}

\subsection{VERTICAL ELECTRICAL SOUNDINGS}

The field sounding curves represent HK type. This indicates there are at least four geoelectrical layers in the survey area. Figure 2 presents the inversion results of the soundings sequence in the form of pseudo-2D section. Figure $2 \mathrm{a}$ shows the one of many interpretation variants obtained by forcing the least amount of layers on the vertical profile. Simultaneously, the logic "continuity" of the interpreted model (within the framework of ambiguity and with reasonable RMS error value) was acquired. It is noticeable that the interpreted geoelectrical layers form the configuration of almost flat-parallel layers with clearly distinguishable resistivities (L1, L2, L3 \& Lb). It is worth noting that the Lb layer (basement) resistivity values are relatively low.

The data obtained from the drilling, with the documented presence of clay sediments (Fig. 2c), was used in the second model interpreted (Fig. 2b). The clay drill core was examined in order to determine electrical properties. Perpendicular measurements were taken several times. The laboratory results point out the presence of resistivity anisotropy. Some examples of the paired results of resistivity and the de- 


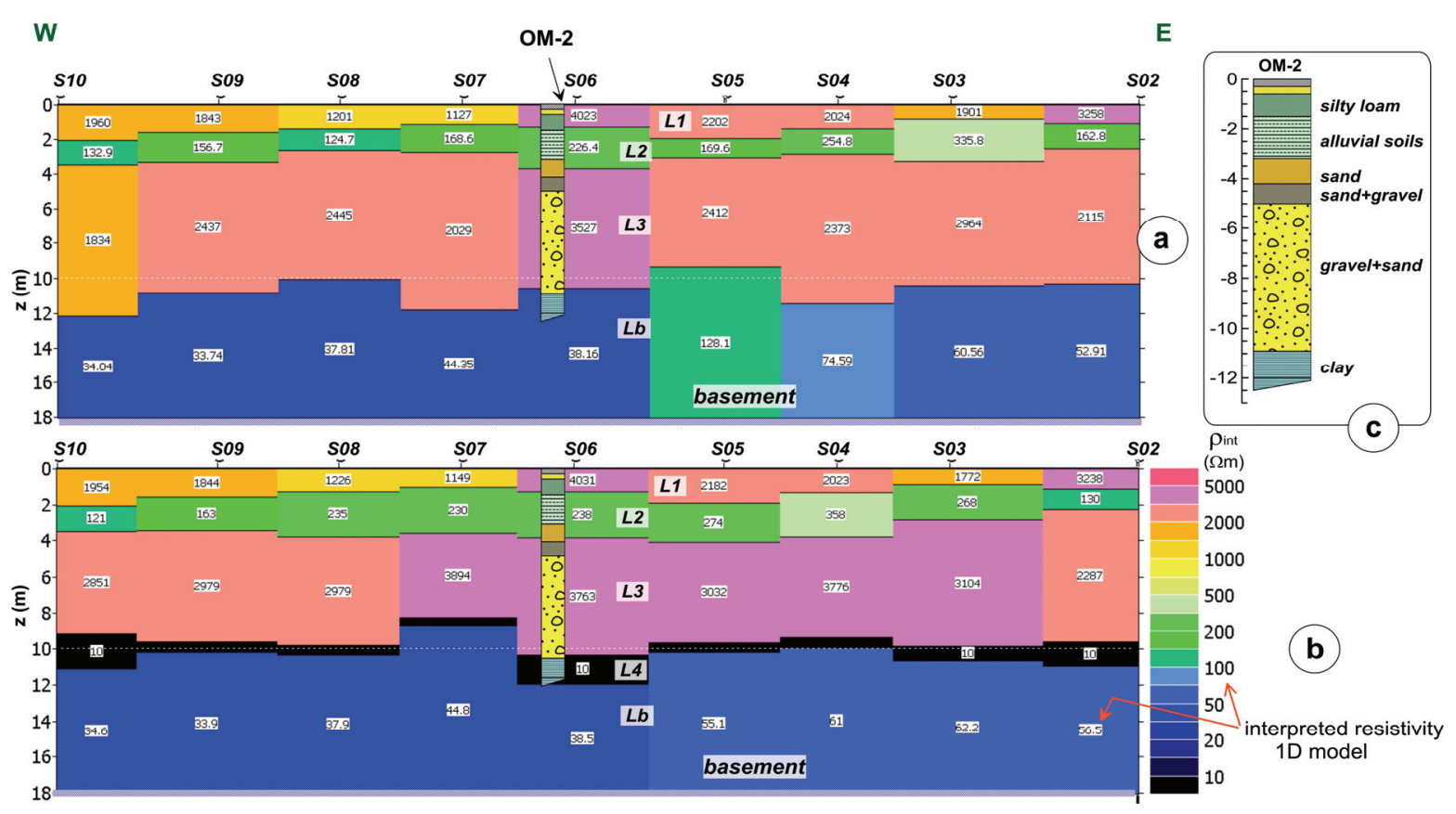

Fig. 2. The VES interpreted resistivity sections: (a) 4-layered model, (b) model with clay layer, (c) borehole profile

termined average square resistivity $\rho_{m}$ are as shown below:

$$
\begin{aligned}
& 7.9 \Omega \mathrm{m} \text { and } 10.3 \Omega \mathrm{m}-\rho_{m}=9.04 \Omega \mathrm{m} \\
& 5.1 \Omega \mathrm{m} \text { and } 10.1 \Omega \mathrm{m}-\rho_{m}=7.2 \Omega \mathrm{m} .
\end{aligned}
$$

It can be assumed that the average resistivity of clays does not exceed $10 \Omega \mathrm{m}$.

In the interpreted model (Fig. 2b) the low resistivity $(10 \Omega \mathrm{m})$ constant clay layer, L4, was assumed to lie below the high resistivity L3 layer. It can be noticed that its presence on the whole section is probable and its thickness can vary. In the presented variant, the permissibly small thickness of the L4 layer was assumed.

The comparison of interpreted sections (Fig. 2a, b) with the OM-2 borehole profile (Fig. 2c), carried out in the VES S06 surroundings, allowed the lithological interpretation to be attributed to the geoelectrical layers.

Near the surface (Fig. 2a, b) the sandy/clayey soils $\mathrm{L} 1$ are present. Their high resistivity character is connected with the vadose zone. Deeper, the relatively lower resistivity (150-200 $\Omega \mathrm{m})$ sediments, with clay fraction addition, are situated and are identified with alluvial soils. Their thickness cannot be precisely defined because of the substantial ambiguity.

In both the models (Fig. 2a, b), the high resistivity L3 layer is visible in $4-8 \mathrm{~m}$ depth range. Due to the very large (as in alluvial origin bearing sediments), rarely noticed resistivity values, it can be identified with poorly sorted, compacted sands/gravels. Lower to the thick gravel layer, the Miocene clays are pres- ent. The depth to clay layer ceiling is about $8-10 \mathrm{~m}$ on average and its thickness probably does not exceed $2 \mathrm{~m}$ (in the VES survey line area discussed). The remaining problem is the character of the Lb layer which is the model's basement. If it would be a limestone basement, the observed resistivities should be assessed as very low. Usually, compacted limestones are characterized with resistivity of several hundred $\Omega \mathrm{m}$ or more. In the case of marl limestone it can be several dozen $\Omega \mathrm{m}$. Resistivity of limestone can also be determined by compactness, karst and bearing grade. It is also possible that the resistivity and thickness of both clays and limestones is locally varied, resulting in a unified Lb layer, especially in the first section (Fig. 2a). It may also be noted that the interpreted resistivity values of the Lb layer are almost twice as high on the east as the west side of the section. This may be in relation to the shape of the deeper limestone basement.

\subsection{ELECTRICAL RESISTIVITY TOMOGRAPHY}

Figure 3 shows the ERT inversion results of the survey lines: ERT-2, ERT-1, ERT-3. The interpreted resistivity sections were completed by the selected results of shallow drilling.

Analysis of the interpreted resistivity sections (Fig. 3) allows us to distinguish, on the vertical profiles, three (in some places four) sharp geoelectrical/geological layers (zones): 


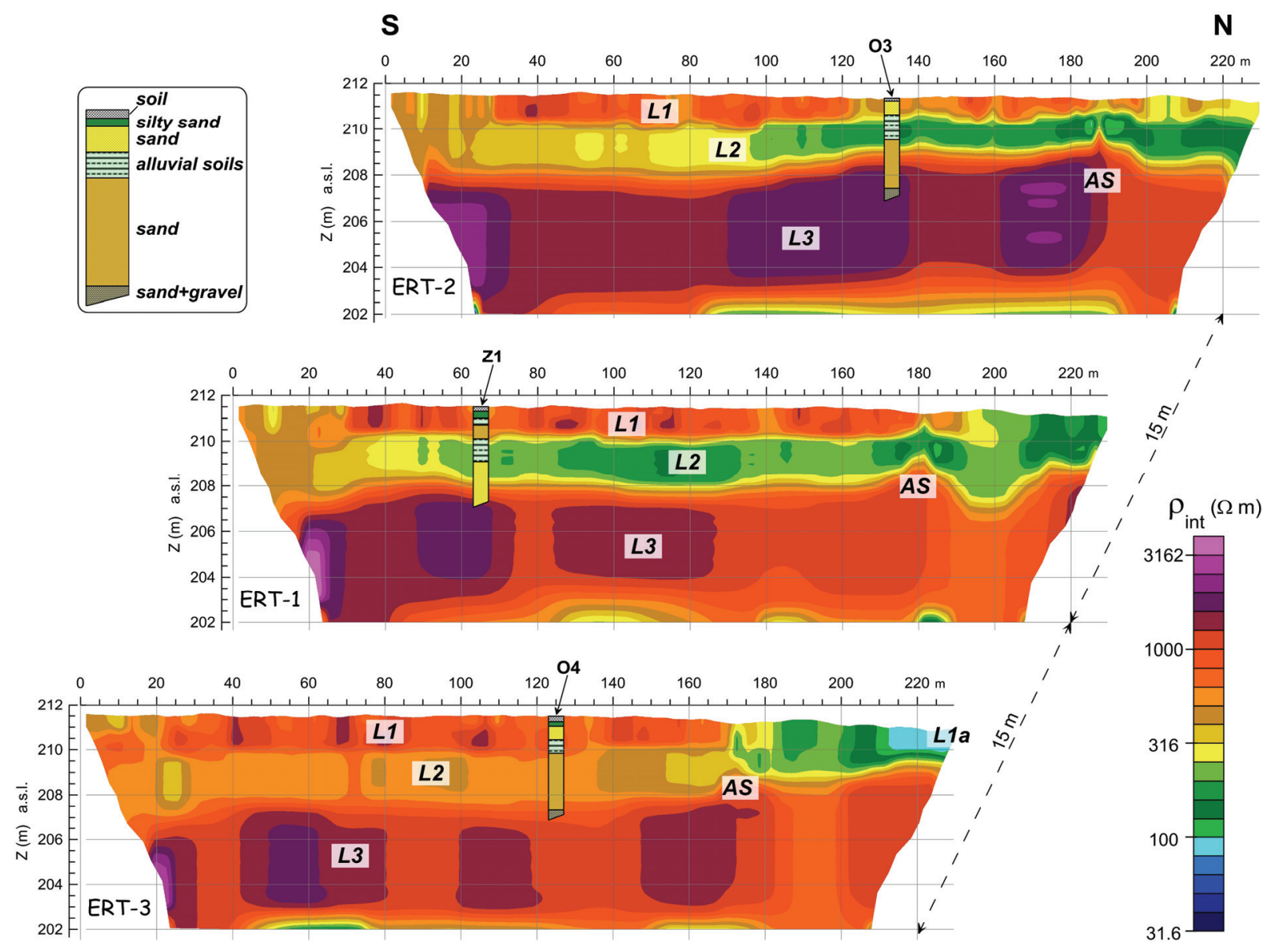

Fig. 3. The ERT inversion results (Res2dinv, 7 iterations, RMS error for ERT-1 $-2.41 \%$, ERT-2 - 2.20\%, ERT-3 - 2.34\%) and selected profiles of shallow drilling (O3, O4, Z1)

- The most shallow, high resistivity surface sediments, L1. They occur mainly in the south and middle parts of the survey lines. The resistivity of the sediments reaches $1000 \Omega \mathrm{m}$ and their thickness is about $2 \mathrm{~m}$. The sediments may be identified with silty sands and sand in the vadose zone. Locally, in the north part of the study area, the layer changes into a layer with a resistivity below $200 \Omega \mathrm{m}$ (increase of the clay component content). This is clearly visible in the ERT-3 profile.

- The underlying layer, L2, with the resistivity value, $<300$ (200) $\Omega \mathrm{m}$, is much smaller than in the first case. The layer has an evident floor, most often 3-3.5 $\mathrm{m}$ below the ground level (above the underground water layer). This layer is dominated by the sediments indicating clay component content. The layer may be identified with alluvial sediments. The results of drilling suggest the presence of alluvial soils. On the ERT-3 profile, the resistivity value is much higher. This proves the content of clay component decrease.

- In the geoelectrical structure L3 sediments dominate and are characterized by very high resistiv- ity values of thousands $\Omega \mathrm{m}$. The layer may be identified with strongly packed and very poorly sorted sands or/and gravels (see VES above). The resistivity changes within the layer stress out the implication of poorly sorted grained rock components. The floor of the layer is not evident in the interpreted resistivity section. Although in deeper part of all the resistivity sections, the low resistivity zones (probably clay layers) are visible.

Furthermore, in all the interpreted resistivity sections (Fig. 3), the structural disturbance, AS, of the high resistivity sediments L2 is observed. This anomalous structure looks like the ceiling "elevation". In the north from the AS structure, the underlying layer is enriched by silty component (resistivity decreasing). It is observed on the ERT-3 profile (zone L1a). The "elevation" is visible in the individual sections.

\subsection{STRUCTURAL MAPS}

The ERT inversion results and electrodes ordinates obtained from the geodetic measurements were used 


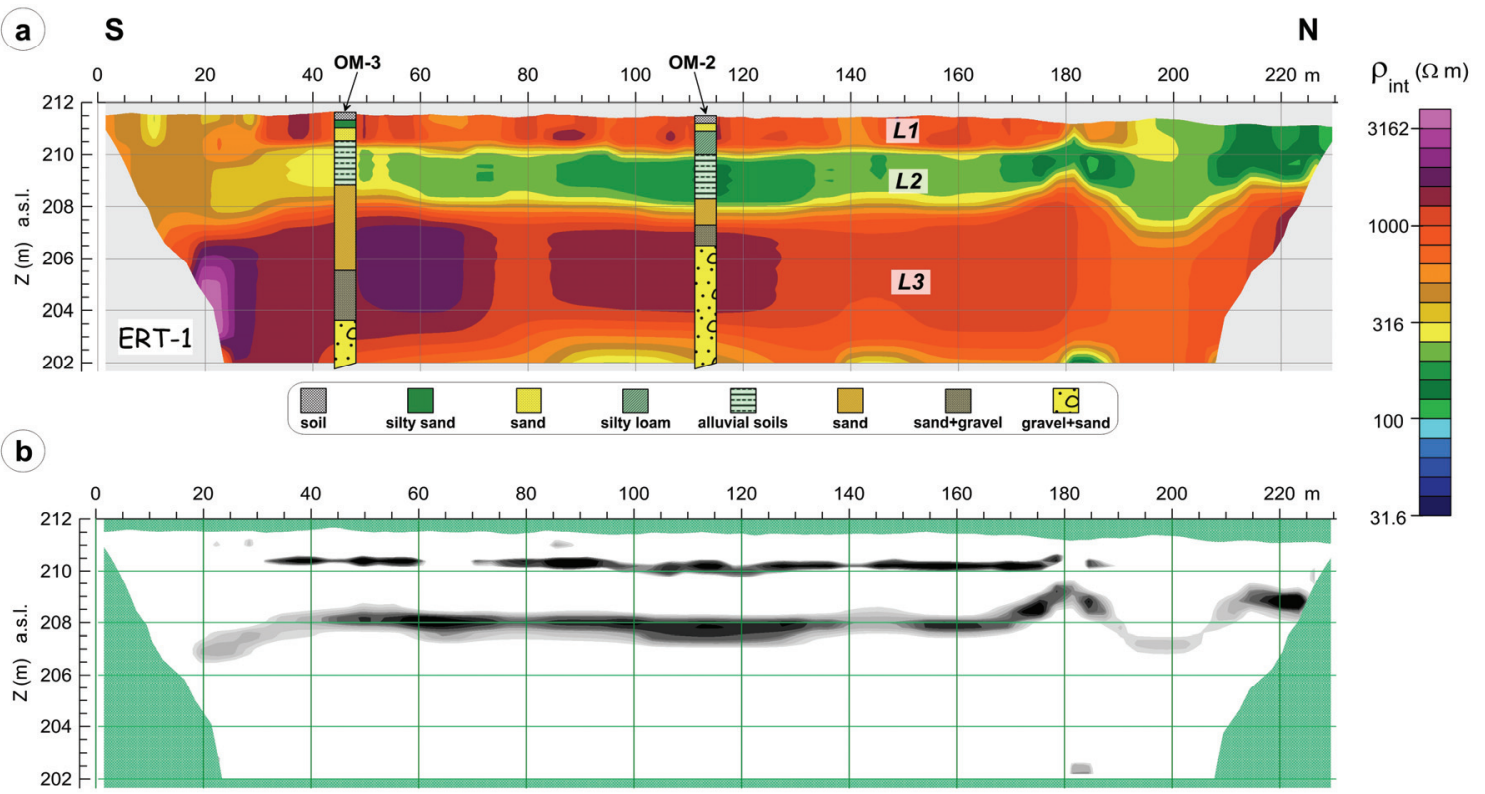

Fig. 4. Inversion results for ERT-1 survey line (a) and extreme values of the interpreted resistivity vertical gradient (b); OM-3, OM-2 - boreholes
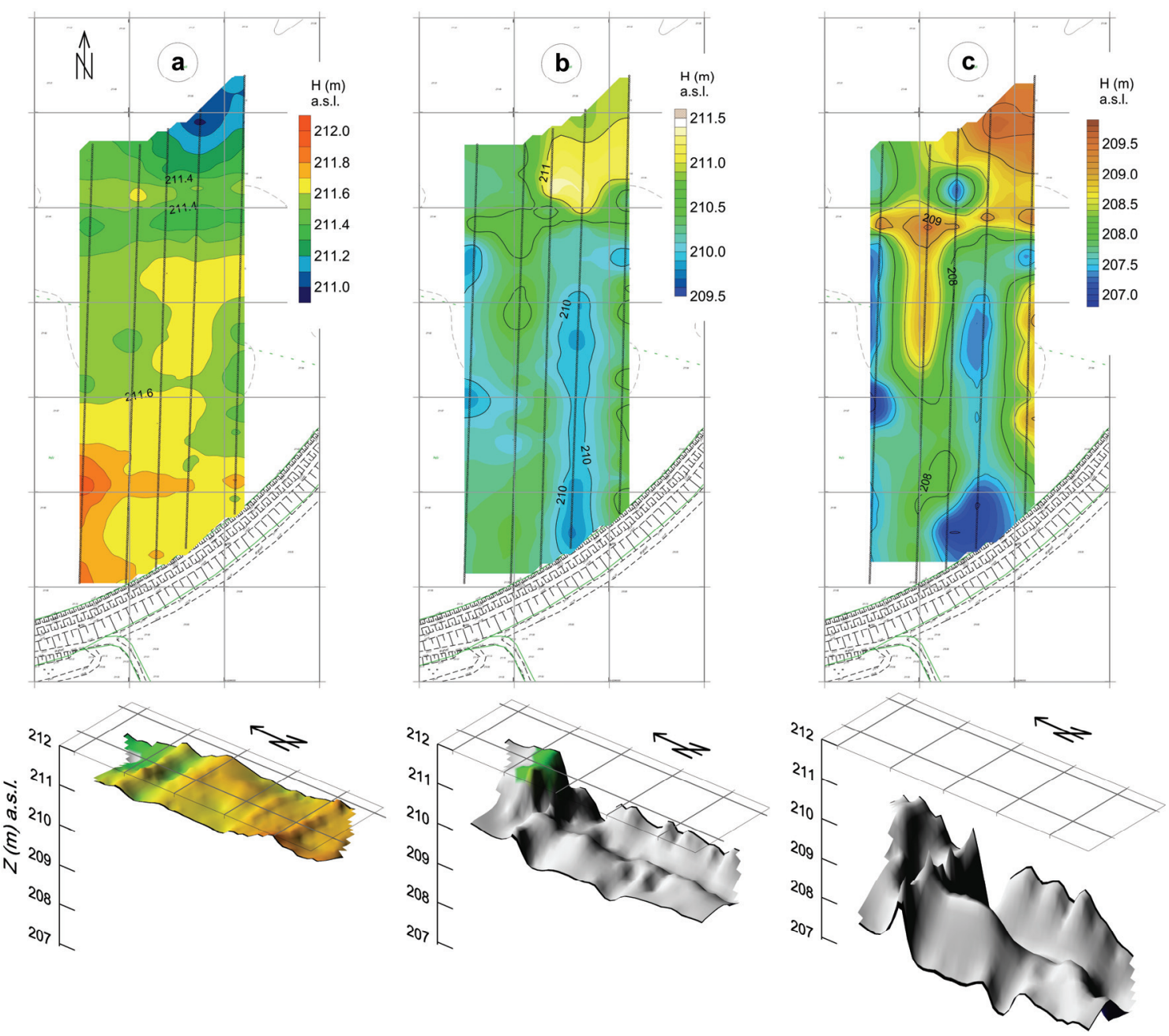

Fig. 5. Topographic map of the surface (a), ceiling of the low resistivity sediments - fluvial soils (b), and bed of gravel/sand layer (c) 
to create structural maps of the near surface sediments. The electrical resistivity of geological sediments changes within a layer. It hampers to indicate the layer range. It is visible when the L2 layer is collated on all the ERT survey lines (Fig. 3). In order to show the depth range of L2 and L3 layers, the interpreted resistivity sections were analysed from the point of distribution of the vertical resistivity gradient (Fig. 4).

The setting of the extreme values may be interpreted as most likely area of contact of geological layers. The numerical values obtained, including localization on the ground surface, were used to create elevation contours of the bed/ceiling for the chosen layers. The contours (Fig. 5) include information from all five survey lines.

The clear NS structures are visible (Fig. 5). However, a correlation with morphology is not visible. Simultaneously, the structural disturbance AS, which is most likely formed in the "gravel" ceiling, runs from the east to the west parts of survey lines and is located in the north part of the map. Additionally, the AS anomaly has its counterpart in the barely visible depression form (Fig. 5a). The forms described can be interpreted as the overlapping activities of the Vistula River.

\section{DISCUSSION AND CONCLUSIONS}

The geoelectrical study showed the presence of distinct resistivity contrasts in the medium. It allowed the range of the different geoelectrical layers/zones to be determined. A comparison of the geoelectrical interpretation results with the geological drilling data/description enabled the lithological identification of geoelectrical layers.

It has been determined that the study area fluvial sediments, such as alluvial soils, are characterized by average resistivity of $150-300 \Omega \mathrm{m}$. They are distinguished from the surroundings as low resistivity zones. Lower lying river gravel and sandy sediments are characterized by very large resistivities, exceeding $2000 \Omega \mathrm{m}$, even below the aquifer. From the geoelectrical point of view, this indicates that the sediments are poorly sorted and their porosity coefficient is low. They are easily and unequivocally identified in the geoelectrical studies. Structures (clays and limestones) that underlie the gravel layer are difficult to classify geoelectrically. The resistivity of clays determined in laboratory studies on their core, does not exceed $10 \Omega \mathrm{m}$ and is characterized by dis- tinct anisotropy. Assuming constant in situ resistivity of clays, based on VES, the clay layer can be identified and its ceiling location can be estimated. However, reliable determination of its thickness is problematic due to the phenomenon of equivalence. The low resistivity value, $30-60 \Omega \mathrm{m}$, of the basement should be noticed. As limestones (with the exception of marly limestones) are usually characterized by much higher resistivities (a few hundred $\Omega \mathrm{m}$ ), such low resistivity may indicate a very diversified depth (due to erosion and/or tectonic) position of the limestone ceiling. In this case, the clay layer and limestone basement appears in the geoelectrical image (from VES) as one averaged layer. The geoelectrical studies provided quantitative information about the spatial presence of the various geoelectrical/geological layers. In particular, Electrical Resistivity Tomography allowed structural maps to be designed showing subsurface structure. It is worth noting that the electrical resistivity distributions (having the character of quantitative information given with high density) often appear differently for the given structure than (less frequent and with qualitative character) the geological data. A combination of these two types of information may result in a much better identification of the geological structure.

\section{ACKNOWLEDGEMENT}

The studies were carried out within the ISMOP project funded by The National Centre for Research and Development, No. PBS1/B9/18/2013.

\section{REFERENCES}

[1] BANIA G., Wptyw topografii na wyniki badań metoda tomografii elektrooporowej - wybrane zagadnienia, Referaty laureatów studenckich sesji naukowych pionu górniczego, Wydawnictwa AGH, Kraków, 2011, 5-15.

[2] BestyŃski Z., Hrabowski W., Pacanowski G., Evaluating the Sealing Efficiency of Flood Embankments with the Use of Geophysical Methods, Near Surface 2008, 14th European Meeting of Environmental and Engineering Geophysics, Kraków, Poland, 15-17 September, 2008.

[3] BoBACHEV A., Resistivity Sounding Interpretation - IPI2Win, Moscow State University, 2010, \{bobachev@rambler.ru\}.

[4] Borecka A., KaczmarczyK R., KrokoszyŃSki P., Ptaszek M., Stanisz J., Korzec K., Kret E., Tchórzewska S., Nowak P., Świątek M., Pękala M., DĄBROWSKI J., Dokumentacja geologiczno-inżynierska wraz $z$ dokumentacja badań podtoża gruntowego sporzadzona $w$ celu określenia warunków geologiczno-inżynierskich dla projektowanej budowy eksperymentalnego watu przeciwpowodziowego na dziatce $n r 796$ w Czernichowie, AGH - UST, Kraków, 2014. 
[5] CASE J.S., Inspection of Earthen Embankment Dams Using Time Lapse Electrical Resistivity Tomography, Ole Miss Project 90034 - Jared Case Master Thesis, May 2012.

[6] DAHLIN T., 2D resistivity surveying for environmental and engineering applications, First Break, 1996, Vol. 14, No. 7, 275-283.

[7] Golonka J., Objaśnienia do mapy geologicznej Polski, Wydawnictwa Geologiczne, Warszawa, 1981.

[8] Johansson S., Dahlin T., Seepage Monitoring in Earth Embankment Dam by Repeated Resistivity Measurements, European Journal of Environmental and Engineering Geophysics, 1996, 1, 229-247.

[9] KALICKI T., MoŚCICKI W.J., Geologiczne i geoelektryczne badania aluwiów paleomeandra Wisty $w$ Zabierzowie Bocheńskim, Przegląd Geograficzny, 1997, T. LXIX, z. 1-2, 158-166.

[10] Koefoed O., Geosounding principles, 1. Resistivity Sounding Measurements, Elsevier, Amsterdam-Oxford-New York, 1979.

[11] LOKE M.H., Rapid 2D Resistivity \& IP Inversion using the least-squares method, Geotomo Software, Manual, 2003.
[12] Loke M.H., Ackworth I., Dahlin T., A comparison of smooth and blocky inversion methods in $2 D$ electrical imaging surveys, Exploration Geophysics, 2003, 34, 182-187.

[13] Mościcki W.J., Characterization of near-surface sediments based on DC resistivity soundings in the Starunia area, foreCarpathian region, Ukraine, Chapter 10 in Monographic Volume: "Polish and Ukrainian geological studies (20042005 ) at Starunia - the area of discoveries of woolly rhinoceroses", Polish Geological Institute and Society of Research on Environmental Changes "Geosphere", Warszawa-Kraków, 2005, 103-114.

[14] MościCKI W.J., Characterization of near-surface sediments based on combined geoelectric studies at Starunia paleontological site and vicinity (Carpathian region, Ukraine), Annales Societatis Gelogorum Poloniae, 2009, Vol. 79, No. 3, 333-342.

[15] Он S., Safety Consideration of Embankment by Conditional Analysis of Electrical Resistivity, Near Surface 2008, 14th European Meeting of Environmental and Engineering Geophysics, Kraków, Poland, 15-17 September, 2008. 